As if to show that the public and private efforts are cooperating, Michael Hunkapiller, president of Perkin-Elmer's Applied Biosciences Division and its top official on the private venture, and Mark Adams, who works with Venter at The Institute for Genomic Research in Rockville, Maryland, were at the conference.

Also present were investigators from the federally funded sequencing laboratories, other university scientists, and officials from $\mathrm{NIH}$ and the Department of Energy, the other major government funder of the HGP, along with representatives of Britain's Wellcome Trust, which recently agreed to fund one third of the total sequencing effort of the human genome (see Nature 393, 201; 1998).

Hunkapiller fielded pointed questions about Perkin-Elmer's intellectual property intentions, and one federal sequencer predicted that the product of the new venture would be riddled with errors, but the overall tone of the gathering was collegial.

Harold Varmus, director of the National Institutes of Health (NIH), declared his pleasure at the private-sector participation, and urged federal scientists to make the public and private efforts "consensusal, communal, collaborative and productive". He added: "There's every reason to believe that we can do that." Hunkapiller said that for the two efforts not to collaborate is "absurd".

The private group promised prompt and full public access to its raw sequence data, but publicly funded scientists and federal officials remain wary. Collins said that, although the venture's leadership was "reassuring" on the question of public access, he worries that "down the road somebody else who ends up as calling the shots may see this as too much of a give-away and retreat". Meredith Wadman

\title{
UK seeks physicists for environmental research
}

[LONDON] Britain's Natural Environment Research Council (NERC) is to introduce a series of fellowships designed to encourage more physical scientists, computer scientists and molecular biologists to take up research on the environment.

"The environment presents the largest, the most serious and the most intractable challenges for the next 50 years," says John Krebs, NERC's chief executive. He says this requires a "new breed" of scientist, and new ways of problem solving that cut across traditional disciplines.

The main goal of the fellowships is to tackle an expected shortage in Britain of environmental scientists with mathematical, computational and statistical skills. A second aim is to involve more natural and social scientists in helping to solve questions in environmental research.

NERC hopes to get molecular biologists to work with ecologists in prospecting for genes from plants with medicinal potential, for example, and in using biotechnology to clean up pollution in soil and water.

The council also wants to see more social scientists working with Earth scientists in research that places values on environmental goods and services, and on the planning and management of towns and cities.

Up to 30 four-year grants could be on

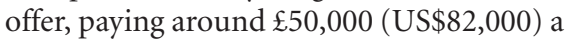
year. The sum includes the salaries of the main postdoctoral researcher and a research assistant, as well as research support.
"The big questions on the environment cannot be solved by one or two narrow disciplines on their own," says Krebs. "Many of the most innovative advances occur at the interfaces between disciplines."

Krebs says that NERC is not downgrading the importance of basic research, but plans to increase its investment in curiositydriven research. It will soon launch five-year response-mode grants for basic research projects; its existing grants last three years.

"Anecdotal evidence tells us that there are not enough people with a physics or mathematics background going into the environmental sciences," says Krebs. "We need to bring such people to help tackle problems in meteorology, hydrology and in the oceans."

The grants and fellowships are expected to be announced after the government's Comprehensive Spending Review, due next month. Both schemes are part of NERC's latest science strategy, which was unveiled at the end of last month. A major aim of the strategy is to remove some of the uncertainty of research careers by tackling the issue of short-term contracts.

NERC's proposed four-year fellowships and five-year basic research grants are designed to provide more stability in research careers, and to encourage longterm interest in a field, says Krebs.

All contract staff employed for more than five years at NERC's research centres and surveys will either be offered permanent posts or released.

EhsanMasood

\section{Australian advisory body's first target is to reduce land salinity}

[SYDNEY] At its first meeting since being restructured, the Australian Prime Minister's Science Engineering and Innovation Council has decided its most immediate task is to find solutions for the rising salinity which is adversely affecting the meagre soils supporting the nation's agriculture.

After more than a century of bush clearance, deforestation and irrigation, salinity has become a major threat to income from exports and the quality of the environment. John Stocker, the chief scientist, estimates that salinity now affects about 5 per cent of the land sown to crops or pastures, and contributes 12 per cent of the yield lost to land degradation.

The state of Western Australia is losing 200 hectares from its wheat belt every day and, with salinization increasing and proving difficult to treat or reverse, saltaffected land is expected to increase sevenfold to 20 million hectares by 2050 .

The move followed the acceptance of a scheme by Stocker for rationally determining preferences for the national support of research and development, which has been an unrealized goal of successive Australian governments. Stocker defines five criteria, which he calls "structural priorities", for assessing the public funding of science and technology.

Stocker argues that research programmes should be gauged by their effects on maintaining the national "science base", developing "applicable knowledge”, promoting "interaction among providers and users" of research, stimulating "innovation in industry", and improving "awareness" of science and technology.

The council has expanded by absorbing the role of the Australian Science and Technology Council (see Nature 391, 624; 1998). Representatives of science organizations have been augmented with leaders of business and grant-giving bodies, and should provide ministers with "highlevel and independent advice", said prime minister John Howard in a statement.

The council told a working party, led by Stocker, to produce by August an action plan on salinity. "We'll have to demonstrate some agility to do it by then," Stocker says. His report may become caught in the last weeks of an (as yet undeclared) election campaign, in which Howard and Kim Beazley, the leader of the Labor opposition, are trading blows about tax reform.

Indications that science is unlikely to figure prominently in the election are reinforced by Howard's not capitalizing on the council's positive outcome to make a political point. But Beazley has called for urgent correction of the Coalition's declining taxation incentives for $R \& D$ in industry.

Peter Pockley 